\section{Pro-Solidarity group objects to governmental appointment}

\section{London}

Poland's "Social Committee for Learning' (the SKN), an unofficial group which campaigns for academic freedom and provides stipends for young scholars and researchers excluded from the academic establishment on political grounds, has issued a strong protest against the appointment of Professor Benon Miskiewicz as chairman of the Central Qualifications Commission, which has the task of conferring senior academic degrees and titles.

Professor Miskiewicz, a former rector of Poznan University, and a military historian by training, was Minister of Science, Higher Education and Technology in 1982, during the period of martial law. He presided over the "pacification" of the universities with what the SKN calls "a brutal sincerity and an unswerving awareness that he was an exponent of the only correct line". Miskiewicz was therefore responsible for the dismissal of a number of academics on political grounds, including a former colleague, Professor Leszek Nowak, who held a tenured lectureship in philosophy at Poznan University and who resigned from the Polish United Workers Party when martial law was declared.

In 1985, Professor Miskiewicz's ministry enacted amendments to the Higher Education Act which annulled the academic autonomy won during the Solidarity period-although a nationwide referendum had revealed almost unanimous opposition of the academic community to these changes. Miskiewicz lost his ministerial post last October, when Poland's two education ministries were merged.

The appointment of someone with such a background is, says the SKN, "an ominous and provocative decision",

For obvious reasons, the SKN does not publish the names of its members, but it is known to include several members of the Polish Academy of Sciences and senior university personnel. This latest protest coincides with a new surge of political unrest in the universities, with the staff campaigning for the restoration of the banned Solidarity-style union groups, and the students demanding the legalization of the Independent Students' Association of the Solidarity period.

Vera Rich

\title{
Relief in sight for HIV-carrying Japanese haemophiliacs
}

Tokyo

Some relief may be on the way for Japanese haemophiliacs infected by blood coagulants contaminated with human immunodeficiency virus (HIV), the virus that causes AIDS. About 40 per cent of Japan's haemophiliacs, or 2,000 people, are believed to have been infected with HIV through blood products imported from the United States.

Japan was slow to introduce heat treatment of coagulants (blood-clotting factors) to kill the virus, but the Health and Welfare Ministry denies direct responsibility and refuses to recognize HIV infection as the side-effect of a drug. As a result, haemophiliacs who are asymptomatic carriers of HIV cannot get full national health insurance cover.

Prime Minister Noboru Takeshita has promised government help. In response, the LDP subcommittee on AIDS, following a proposal from the Ministry of Health and Welfare, has recommended that Japan be divided into eight or nine regional blocks in each of which key university and national hospitals will be asked to act as bases for the treatment and counselling of haemophiliacs with AIDS problems.

Government money will be used to cover the costs of treating asymptomatic patients and there will be measures to cover the extra bed costs of hospitalized haemophiliacs suffering from AIDS. But haemophiliacs are not satisfied. The $\mathrm{Na}$ tional Association of Haemophiliacs has submitted a written demand to the Health and Welfare Ministry for "complete relief measures" from the government, including adequate compensation and the best possible treatment for those infected.

A Kyoto-based group of "victims of imported blood products" is demanding compensation for the families of victims who have already died, and "sympathy money" and annuities for living expenses for those with AIDS.

The ruling party is also hoping to reopen deliberations on the controversial new 'AIDS Prevention Law' which has been stalled in the Diet since last year by opposition from lawyers, physicians and haemophiliacs who say the law will violate patients' human rights. Yoshiaki Ishida, for the Kyoto group, says the subcommittee's recommendations are a step in the right direction, but if the proposals are tied to acceptance of the new AIDS law, they are "nothing to be happy about",

\section{Australian fracas}

Mount Etna, in Rockhampton in Queensland, has become the scene of a bizarre confrontation between environmentalists and the owners of the mountain, Central Queensland Cement. Mount Etna provides the company with limestone worth some A\$18 million annually. But now Central cannot carry out the blasting needed to extract more limestone. Conservationists, led by Mr Craig Hardy, have hidden themselves in the vast warren of caves within the mountain. They say they will stay there. They aim to save the 46 named caves and a rare colony of bats, and have food supplies to last months.

"Hundreds of people are telling us to blow them up. But we're a responsible company", explained Central's general manager, Mr Robin Town. Time may be on the company's side, though, because there are stockpiles of enough limestone to last 5 years. Untapped reserves are estimated at 30 years' supply.

T.E.

\section{FRG/China deal}

A NEW agreement will make it easier for researchers in West Germany and the People's Republic of China to collaborate. It was signed by representatives of the Deutsche Forschungsgemeinschaft (DFG) and the National Natural Science Foundation (NSFC) in Peking on 25 March. The agreement complements other pacts between the two countries. Over 500 researchers have gone to China from Germany since 1974 under the auspices of the Max Planck Society and the Chinese Academy of Sciences. The DFG made a similar agreement with the Chinese Academy of Social Sciences in $\mathbf{1 9 8 1 .}$

S.D.

Universities neglected

China is devoting too few resources to too many universities, according to Professor Ding Shishun, president of Beijing University. "Some leading comrades" pay attention only to building and running factories, and cońsider education a "soft" task, he said. Instead, Professor Ding called for China to follow the example of postwar Japan and West Germany, which invested in education in spite of severe economic problems.

V.R.

\section{AIDS vaccine first}

Encouraging results have come from the United States' first human trials of an AIDS vaccine. Joseph Kovacs of the National Institutes of Health and colleagues reported at the American Federation for Clinical Research's meeting that six of $\mathbf{1 5}$ volunteers who received a $\mathbf{4 0}$ microgram dose of recombinant gp160, the envelope protein of the human immunodeficiency virus, showed an antibody response to gp160 after eight weeks. Higher doses of gp160 and the nature of the antibody response will now be investigated. A.A. 